\title{
Christian and Buddhist approach to religious exclusivity. Do interfaith scholars have it right?
}

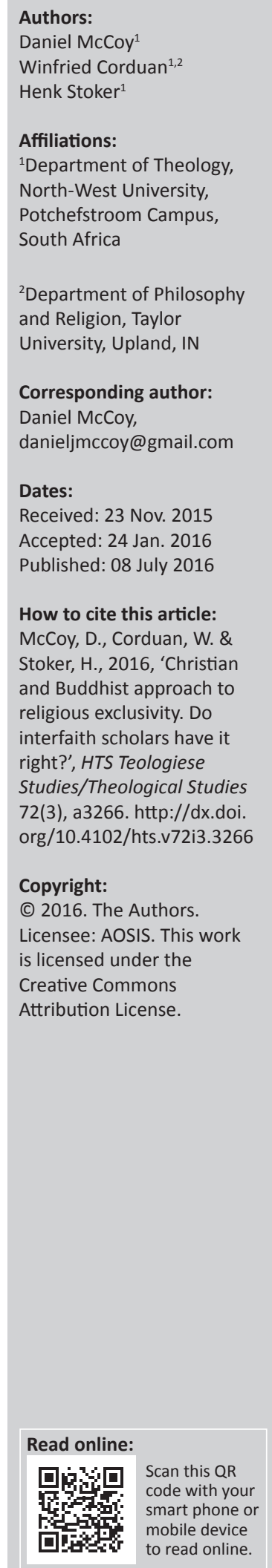

Buddhist-Christian interfaith scholars ${ }^{1}$ are quick to denounce what they perceive as religious exclusivity. So when it comes to the major views on just how true and salvific the religions can be, it is no surprise that Exclusivism is ruled out automatically. What is surprising is how inevitable it is that when Buddhist-Christian interfaith scholars commit to any view - whether Inclusivism, Pluralism, or Relativism - they themselves end up committing the sin of exclusivity. Whatever view they entertain turns out to be too exclusivistic for somebody, by having too particular a saviour (Exclusivism), too particular a salvation (Inclusivism), too particular a metaphysics (Pluralism), or too sceptical a religious outlook (Relativism). ${ }^{2}$ To make matters worse, the further the interfaith scholar cycles away from Exclusivism in an attempt to elude exclusivity, the further she wanders not only from Christianity, but from Buddhism as well. Thus, by attempting to unite the two religions, the interfaith scholar finds herself at odds with both sides. Truly, it seems the interfaith scholar has no place to lay her head. By consulting interfaith scholars' own writings, this paper describes their dilemma in finding such a place.

\section{The best, a best, or no best}

Infallibility might work in the creeds, but no one enjoys being around it in real life. If in romancing the religious other, you manage to distance yourself as far as possible from the category of 'incontestable rightness', you might alienate the base, but you will certainly win the congratulations of the interfaith community. If such is the goal - to avoid being right so as to not be thought of as wrong - which religion's leaders have the edge? In an interview with Christianity Today, the closest the Dalai Lama got to claiming 'rightness' was to say, 'I can say that for me personally, Buddhism is best because the Buddhist approach is most effective to me' (Beverley 2001:69). Who could imagine the Pope - even one as approachable as Pope Francis - claiming that Catholicism is best for him because it works best for him! There is just not the kind of elbow room we find in Buddhism for any kind of Christianity that is bound to any measure of infallibility.

\section{Exclusivism, Inclusivism, Pluralism, and Relativism}

In interfaith dialogue, the point is often hazily defined - if defined at all - as getting along better (Phan 2006:105), accomplishing altruistic work better (Knitter \& Abe 1988:349), getting to know other 'truths' better (Gross 2005:15), and so on. Being too specific about the goals of dialogue risks one party imposing an agenda. But there is one unmistakable objective presupposed if not mentioned in every lecture, paper, and discussion. Such a goal - unique in its explicitness - is to remove any and all traces of exclusivism. ${ }^{3}$ It is unfortunate to use such a metaphor for such peace-loving folk, but it is as if they 1.By 'Buddhist-Christian interfaith scholars', we mean scholars who propose some kind of essential synthesis (i.e. combining and
or relaxing essential doctrines) of Christianity and Buddhism. As described in Daniel McCoy's doctoral thesis $A$ comparison of
Buddhist compassion to Christian love (McCoy 2015), there are multifarious proposals for how the synthesis can be done. What
further unites most attempts is a propensity to tweak Christianity to make it more like Buddhism, rather than the other way
around. Obviously, all these synthesis-minded scholars and their proposals cannot possibly be described, much less assessed, in
an article of this size. For a description of fifteen ways these various scholars have proposed for synthesising the two religions,
consult chapter 2 of the doctoral thesis (McCoy 2015:19-140). This article should not be seen as an overall description, much less
a meta-analysis, of a monolithic group called 'interfaith scholars'. Rather, this article is merely an exposing of the exclusivistic
propensities of three soteriological views championed by scholars who nonetheless eschew Exclusivism in proposing a Buddhist-
Christian synthesis. That there are three soteriological views described in this article accounts for the diverse spectrum of
scholars cited.

2.This article does not attempt to disprove Inclusivism, Pluralism, or Relativism in general. Neither does it even attempt to refute Buddhist-Christian scholars who hold Inclusivism, Pluralism, or Relativism. The point is merely to point out that such scholars are unsuccessful in escaping exclusivistic tendencies, and that, moreover, such attempts further drive a wedge between such scholarship and the earliest forms of Christianity and Buddhism.

3.Jeffrey Carlson (2003:82) recaps interfaith sessions with the following description (which he also uses to describe an interfaith text): 'Buddhists (most of whom used to be Christians) critique Christian exclusivism, while Christians (most of whom are pluralists) critique the same thing'. Similarly, Archbishop Rembert Weakland (2008:94) recalls the lone aim of one such conference he presided over, an aim which he articulated in his opening greeting: 'We come not to civilise, not to conquer, not to convert, but to be here'. 
band together as allies to withstand a common enemy. This common enemy is clearly defined - or is he? (see Figure $1^{4}$ ).

You will notice the common three categories of how religions relate to truth, going clockwise, as Exclusivism, Inclusivism, and Pluralism. Please note that the Relativism that finishes the clockwise cycle is a very strong type of Relativism, such that there is simply no metaphysical truth whatsoever, not accessible because it is not even existing as 'Real'. The strong Relativism envisioned in this final quadrant is to be distinguished from the relativism that undergirds Pluralism in the third quadrant. An example of this third quadrant would be John Hick's theology, according to which there is a Real to which all the paths point, albeit inadequately because, according to Hick, we cannot really know anything for sure about it.

The categories 'pessimistic/optimistic' and 'experience/ revelation' indicate continuums. Exclusivism is not necessarily pessimistic (if exclusivists were always pessimistic, how could missionaries get described as 'triumphalistic?'). The idea is that Exclusivism is more 'pessimistic' than Inclusivism when it comes to the question of who is saved in the end. Likewise, each quadrant comes in degrees, so that, for example, the more optimistic the Inclusivist, the less she will hold that sincere believers of other faiths will be saved through Christ, and she will believe that absolutely every believer of whatever faith will be saved (universalism). Using this diagram as a template, let us try to isolate the problem of exclusivity. ${ }^{5}$

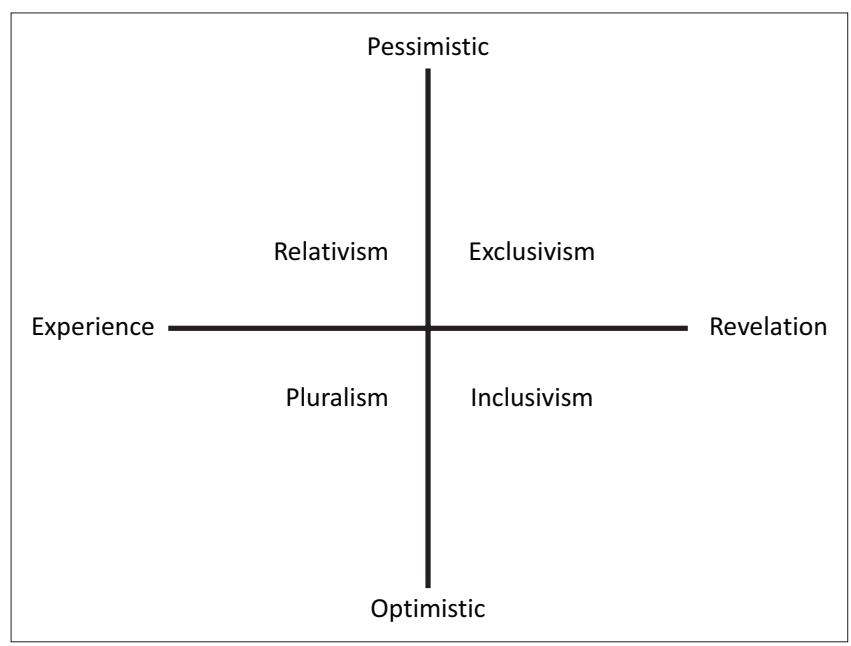

FIGURE 1: Progression from Exclusivism to Relativism.

4.This figure is original to the authors. The two axes chosen (i.e. Pessimistic and Optimistic, Experience and Revelation) are not crucial to any argument given in this article. Rather, the mapping is merely one way to show the progression (i.e. clockwise according to this model) from what is usually held to be mos exclusivistic (Exclusivism) to what is typically thought to be least exclusivistic (Relativism). The article could conceivably do without these axes and merely list the four in a row in descending order of perceived exclusivity (Exclusivism, Inclusivism, Pluralism, and Relativism). However, the axes are included since arranging them in these four quadrants does provide some helpful insights about the views, while (most importantly) providing one way to visualise the descending order of exclusivity. (Another way to visual the progression is by another metaphor employed in the article, that of erasing the lines and 'widening the circle'.)

5.Netland (Knitter \& Netland 2013:35) mentions that the traditional categories of Exclusivism, Inclusivism, and Pluralism are somewhat unhelpful because they simply cannot capture all 'different, very carefully nuanced perspectives'. This seems like a true observation. However, because no widely agreed upon categories have risen to replace these, it seems best to use them here.

\section{Exclusivism - all can be saved (but some will be lost)}

It is clear that, if exclusivism is the enemy, then interfaith dialogue would obviously not welcome any position so far gone that it would actually label itself as 'Exclusivism'. ${ }^{6}$ To be clear, 'exclusivistic' describes views (e.g. 'That view is too exclusivistic'.), but it also is a view (e.g. 'That Evangelical identifies himself as an Exclusivist'.). Now, before the actual tenets of Exclusivism are even presented, one unfortunate reputation precedes it. As religious scholar Douglas Cowan (2000) documents, many Exclusivists writing on Buddhism have shown themselves to be often misinformed and sometimes downright unpleasant. Here are some examples of obviously sloppy scholarship: The core of Zen is said to be 'love of self first, last, and always' (Cowan 2000:27). Buddhism was a 'violent protest against Hinduism' (Cowan 2000:35). Buddhism and Hinduism are simply forms of each other, and fit nicely under the category of 'New Age' (Cowan 2000:35).

But instead of focusing on obviously unfortunate samplings of Exclusivists, will a definition help dig Exclusivism out of its hole? What is Exclusivism? Perhaps the best way to define it in such a way that captures the full shock it gives interfaith scholars is through a story. Shin Buddhist Kenneth Tanaka (2005) recounts:

In one of our sessions a few years back, the discussion moved to a topic of the nature of 'ultimate path', which, as it turned out, began to raise some extremely sensitive issues. An unusually tense atmosphere hung over the discussion table, a rare turn of events for our usually jovial dialogue group composed mostly of liberal-minded members. One of the Christian members gave voice to her fundamental view that Jesus was the sole path through which one can be saved. It was clearly what anyone would regard as an exclusivist position. In asking for further clarification, she reiterated her view that her Christian faith necessitated that she took that position, and that I as a Buddhist was, therefore, not included in that soteriological scheme. I responded to her that I understood that I would not be in her scheme because I was not Christian, but would I nevertheless be saved? After some hesitation, in so many words, she replied that I would not be! Had she been a member of a more conservative group, it would have been easier to accept that kind of a response, but coming from an academic with liberal leanings, her comments caught me off guard. (p. 41)

An Exclusivist is diagnosed by interfaith scholars as those who insist on dividing people, in the words of Koyama (2002:80), into 'two groups: the saved and damned, children of light and children of darkness, people inside the ark and people outside the ark, the follower of true God (Yaweh) (sic) and false God (Baal), the chosen and gentiles, and sheep and goats'. They see antagonism where there could be complementarity because they are doggedly 'reacting to the increased awareness of religious diversity by reinforcing one's own identity against all others rather than creatively transforming and developing one's identity through mutual integration or even interpenetration' (Schmidt-Leukel 2003:267).

6.When used as the official viewpoints being discussed, Exclusivism, Inclusivism Pluralism, and Relativism will be capitalised. If used as descriptive (e.g. exclusivistic, relativistic), they will be lower cased. 
Now, admittedly, not all traditional Evangelicals are clumsy with facts or even unpleasant. Evangelical scholars Keith Yandell and Harold Netland are applauded for providing 'an exemplary model for future evangelical discussions of Buddhism' (Yong 2011:103), for they have done their homework and avoid constructing straw men. They evaluate Buddhism 'respectfully and with dialogical rhetoric quite different from the kinds of polemic deployed by prior generations of evangelicals' (Yong 2011:104). However, in the end, they are guilty of presuming 'either/or logic' and remaining 'at the level of philosophical discourse and analysis', and thus miss the more fruitful commonality that comes at the level of religious practice. According to interfaith scholar Amos Yong, Yandell and Netland, gracious as they are compared to most Evangelicals, are nonetheless lacking in interconnection and hospitality (Yong 2011:112-113).

In other words, there is a problem with Exclusivism besides its misinformed, misanthropic, reputation. The very idea that one religion uniquely offers salvation with no guarantees given to adherents of other religions is seen as problematic even if the disposition is kind and the scholarship impeccable. Gross (2005) explains why. According to Gross, a pluralist is not, in fact, obligated to accept all beliefs as true. She calls beliefs pluralists cannot accept 'absolutist': 'The absolutist does not tolerate tolerance or the coexistence of multiple religious systems. This means that the pluralist is ill-advised to regard religious absolutism as simply another point of view' (Gross 2005:18). One reason given for why pluralists cannot accept absolutist views is that absolutist views do not accept pluralist views. She continues, 'Such openness [to absolutistic views] would eventually result in the elimination of the pluralist'. So, according to Gross, it is an oversimplification to say that pluralists applaud all beliefs equally: 'Pluralists claim that multiple religious symbol systems can coexist without needing to be ranked ... But pluralists do not claim that all religious symbol systems are equally valid' (Gross 2005:18). One might ask what makes a belief system valid or invalid. Gross answers, 'One criterion is paramount: Does a religious belief help or hinder human and planetary well-being? Does it do what religions are supposed to do, that is to promote positive human transformation?' (Gross 2005:19).

If the point of religions is to promote human transformation and planetary well-being, ${ }^{7}$ then it should seem that Christianity would receive Gross's applause, so long as Christians hold their beliefs as true but not use them to hurt people. However, such a happy presumption would be premature. According to Gross, the problem is not merely the forcefulness with which one imposes the belief, but the forcefulness with which one believes it:

7.Many Buddhist-Christian interfaith scholars speak candidly about their motivation for synthesising Buddhism and Christianity: they believe the synthesis to be only right since they see it as the best way to a more peaceful world with less suffering. right since they see it as the best way to a more peaceful world with less suffering. This underlying motivation for the synthesis is no surprise since many of them see better world with less suffering to be the standard of what makes a religion good in the first place (see McCoy 2015:131-134 for a description of the scholars motivation for the synthesis and standard for a religion's goodness). Where particular religion's truthfulness is seen as less discernible (i.e. as it is said to be by the aforementioned interfaith scholars), its goodness can still be ascertained, especially if put in terms of this-worldly functionality.
Exclusive truth claims on the part of any religion are unacceptable to pluralists not because of whatever metaphysical ideas such religions may put forth, but because of the ethical consequences of their claim to exclusivity. (Gross 2005:19)

Yet one wonders how truth claims can have ethically unacceptable consequences if one holds them kindly. Gross explains, "Their claim to exclusive truth lands them in the ethical position of causing harm to others by denigrating the religions of others and using all possible methods to get them to change religious allegiance' (Gross 2005:20). She goes on to categorise these methods: 'All possible methods have included physical force and often include psychological coercion ...' Of course, embarrassing uses of physical force chronicled in church history books are commonly apologised for and repented of; Christians can accommodate Gross's grievances in that category. But what exactly does Gross see as 'psychological coercion?' They 'often include the psychological coercion of threatening others about eternal consequences for not converting to the perspective of the religious exclusivist'.

In other words, physical force is put into the same category as psychological coercion, which, when defined, translates to 'You won't be saved otherwise', and hence simply restates the Exclusivist position. That is, Exclusivism should not be tolerated by the Pluralist because it can cause physical force, but even when it does not, then Exclusivism should be not be tolerated because it is Exclusivism. However helpful religions might be, we are warned, 'when absolute and exclusive truth claims attach to them, they become intolerable monsters' (Gross 2005:20). This goes even when they foment nothing more monstrous than a Bible college graduate crossing the sea with a Bible in her hand and 'love for the nations' in her heart - still intolerable because she includes in her presentation the fact that Jesus talked a lot about hell. That counts as psychological coercion. Besides, 'Such beliefs about exclusivity always have imperialistic and harmful consequences', not the least of which is that 'it is a point of view that would eliminate its rivals if it could' (Gross 2005:20), not the least of which is Pluralism itself. Now, to clarify, eliminate can mean 'to kill' or 'to convert'. Let us not go reading the worst of church history as a present-day newspaper and plant sensationalistic rumours that Christians are going around beheading those of other faiths. On the other hand, if eliminate means 'to convert', then are we meant to believe that Pluralism in turn does not also wish to 'eliminate' its rivals? Having not clarified the meaning of 'eliminate' (but indicating that it has to do with either physical force or psychological manipulation), Gross would assure us she has no wish to do anything so drastic. But somebody at some point needs to clarify the difference between 'eliminating' and 'relativising' a religion to nothing more than 'language-based truth claims and symbol systems' (Gross 2005:18). ${ }^{8}$

8.This section should not be read as an attempt to prove that Exclusivism is the true soteriological scheme. Rather, Gross's assessment of Exclusivism is articulated to allow a renowned Buddhist-Christian interfaith scholar to explain the key reasons Exclusivism a renowned Buddhist-Christian interfaith scholar to explain the key reasons Exclusivism
is unacceptable. Moreover, Gross's position (Pluralism) is not being assessed here; rather, Pluralism's exclusivistic propensities will be discussed in Section 2.3. 


\section{Inclusivism and/or Universalism: all will be saved}

So, not surprisingly, Exclusivism is too exclusivistic for these interfaith scholars. Its good news of 'All can be saved' presupposes too particular a saviour. What about the next clockwise step: does Inclusivism escape the charge of exclusivity? Of course, Inclusivism is definitely seen as going in the right direction. Interfaith scholars point out how Nestorian missionaries in the seventh to ninth centuries were commendably quite inclusivistic in their dealings with Chinese Buddhists (Scott 1985:92-93). In fact, using the philosophical second century Justin Martyr and the twentieth century Second Vatican Council as bookends, Corless (2007:107-108) sees the Exclusivism of Christianity as something negotiable, and indeed only basically universal from Augustine through to the Reformation.

However, Inclusivism - appreciated as it is for its good intentions - wins no points for being any great step out of exclusivity. In fact, Inclusivism might even be perceived as more insulting to the religious other than Exclusivism! This is because whereas the Exclusivist is content to take the religious other's claims at face value (albeit as false), the Inclusivist often presumes to know better what the religious other really believes (e.g. 'You might think you are a Buddhist, but you are really an "anonymous Christian"'). According to Yong (2011:106), 'the inclusivist vision finally subordinates the insights of the alien faith to that of the home tradition'. When the innovative Thai Bhikkhu Buddhadasa interpreted Gospels using 'Dharma language', he 'may be criticised for claiming the right to define what Christianity is really about, and in doing so closing the doors for further constructive dialogue' (Haug 2006:77). Comparative theology scholar James Fredericks describes the Buddhist reaction when Christians interpret their Dharma using 'Gospel language':

By casting the question within the framework of Christian soteriology, Catholics continue to talk to themselves ... The debate among Catholic 'liberals' and 'conservatives' over how other believers are saved seldom takes into account the teachings of the other religious traditions. This amounts to a subtle triumphalism. Catholic 'liberals', following the course charted by Karl Rahner, want to recognise other religious traditions as the work of the Holy Spirit. My own Buddhist friends assure me that this is not the case and that I will never appreciate the Dharma to the extent that I persist in this belief. How are Shiite Muslims and Vajrayana Buddhists to react to assurances by Catholics that they are saved by Christ? Perhaps they react the way Catholics do when they learn of Hindu groups who teach that Jesus of Nazareth is an avatar of Lord Vishnu. (Fredericks 2003:253)

Knitter (Knitter \& Netland 2013:28-29) summarises the situation as 'at one time just about all the churches held firmly that Christianity is the only true religion, today many churches do not. My Roman Catholic community is an example of a major Christian denomination that, as it were, has changed its mind ...'. Then he summarises the typical interfaith response: 'This means that more change can come ... [I]f the church has shifted from exclusivism to inclusivism ... a further shift from inclusivism to pluralism would seem to be possible'. Could Inclusivism still be true? Such a question is obviously for a much larger project. What we can say with confidence is that, for some scholars, Inclusivism is too exclusivistic.

\section{Pluralism: all paths will save}

So, whereas the Exclusivist good news that 'All can be saved' offers too particular a saviour, the Inclusivist and/or Universalist good news that 'All will be saved' offers too particular a salvation. So the circumference has to widen again. The next step, in order for neither saviour nor salvation to be too particularly defined, is to claim that all paths will indeed save. Of course, John Hick paints himself with a rather conspicuous target for explaining exactly how all religions can be said to be true. Hick (2006) starts with the Kantian dictum that God is fundamentally unknowable in essence. Thus, any statement about God is necessarily a statement about one's own experience with God as unique manifestations of the unknowable. And, of course, how can one be wrong about her own experience of the ineffable, even if it contradicts another's? Hick's vulnerability lay in his decision to call the Ultimate by a name - a vague name to be sure - but a name nonetheless.

Hick's pluralist position assumes that no one religion is definitive, but that each attempts to articulate an ineffable ultimate reality that Hick calls 'the Real'.

Yet Hick's pluralistic hypothesis harbours a curious inconsistency: he does not allow various religions simply to coexist. Instead, he imposes an additional global meta-theory about 'the Real' that entails specific theological claims of its own. Hick contends that the various conceptions of the absolute Trinity, Allah, Brahman, Sunyata - refer to a different 'persona' or 'impersona' of the Real. In Kantian terminology, they are all 'phenomenal manifestations of the noumenal real-in-itself'. Hick thus demythologises each religion, or 'phenomenal manifestation' of the Real, on the basis of his meta-theory of 'The Real', which becomes the privileged account of ultimate reality (Brown 1999:167-168).

At least in Buddhist-Christian dialogue, Hick is consistently helpful in making it clear what position one is not. Although many claim to be 'genuine' pluralists, Hick is often dismissed as a pseudo-pluralist. We might ask why. The charge is that he charted a metaphysical summit, even though it is fundamentally impenetrable through the epistemological fog. 'The Real' subsumes the rest. In contrast, there are the 'real' pluralists such as John Cobb. Cobb calls himself a 'radical pluralist' (Fors 2006:82). Whereas he charges Hick with treating the religions as if each major object of devotion is another name for the same reality, Cobb sees the religions as fundamentally different from each other and reconcilable because of their puzzle piece-like differences. Because, in keeping with this difference, he holds that each religion is only analysable according to its own norms, Cobb can claim, 'So am I affirming Christian uniqueness? Certainly and 
emphatically so! But I am affirming the uniqueness also of Confucianism, Buddhism, Hinduism, Islam, and Judaism. With the assumption of radical pluralism, nothing else is possible' (Fors 2006:83).

Hick makes epistemologically impervious metaphysical claims, but Cobb claims nothing except what each religion claims for itself. However, it should be noted that Cobb's dialogue has not been with each religion, but with Buddhism. Moreover, it is significant that Cobb's Buddhist-Christian dialogue works precisely because Cobb is theologising from a process theology model. His god is in process; otherwise, his god could not be made to fit into the emptiness of Buddhist metaphysics. Cobb holds that emptiness is the ultimate reality, whereas his god is the ultimate actuality of that reality. "They are two different ultimacies interrelated with each other' (Fors 2006:88). This alliance has led some to criticise 'Cobb as seeking confirmation in Buddhism for what he already knows through his Whiteheadian Christianity' (Fors 2006:92). Quite obviously, Cobb advocates a particular metaphysics, but it is simply one amenable to some Buddhists and some Christians and thus is not dismissed as pseudo-pluralism. Yet somehow Hick has been declared guilty of imposing his metaphysics with the enigmatic 'Real', whereas Cobb has supposedly stumbled upon a truly universal pluralistic system. However, it is doubtful whether the process god-emptiness synthesis can sail very far toward other seas with its anchor in BuddhistChristian dialogue. Even if all the religions could somehow be fit into the scheme of Buddhist emptiness, how is this less of an imposition than fitting the religions into a far less defined 'Real'?

As it turns out, the heroes of the Buddhist-Christian relationship, those truly able to straddle both worlds, all land somewhere, and tend to plant their flags in more concrete metaphysical ground than the 'Real'. Like Cobb, Paul Ingram, the Lutheran is hailed as a pluralist who 'rather than adopting the Kantian epistemology and its agnosticism' nonetheless 'defends a Whiteheadian process philosophy and metaphysics' (Yong 2011:108). Likewise, Shin Buddhist Yokota (2002:143-145) criticises Hick's position as 'still disguis[ing] an unintentional religious imperialism', but who nonetheless owes his own system 'much, if not all, to John B. Cobb's work in interreligious dialogue and its general philosophical and theological orientation derived from Whiteheadian process thought'. And unlike Hick's endeavour to be a pluralist with regard to all religions, Yokota admits, 'Christianity is the only other religious tradition with which I can adequately converse'. Knitter (2012:22), the Catholic is clear that his Buddhist-Christian synthesis is possible because although Christianity provides the 'living color', it is Buddhist metaphysics that provide the 'big picture'. Indeed, his is a union between 'Buddhist Ontology and Christian Particularity'. The point is that Hick is not alone in having to land somewhere metaphysically. Yet he is 'imperialistic' for having done so. Now, could Cobb and company have stumbled upon religious truth? Nothing in this article has precluded such a possibility. But it cannot be said that these
Pluralists escape exclusivity. Perhaps the solution is to expand the circumference once more.

\section{Relativism: all beliefs are safe}

The three traditional categories of how religions relate to truth - Exclusivism, Inclusivism, Pluralism - tend to invite criticism. It is often easy to detect in Buddhist-Christian interfaith scholars irritation toward the categorisation. These scholars tend to castigate the first two options and only identify with the third in a highly nuanced way. They claim to be Pluralists, but in an unequivocally non-Hickian sense that nonetheless shows a metaphysical preference for something that fits Buddhism and/or Christianity. Those with process theology or emptiness metaphysics might be able to be 'pluralists' when it comes to the two religions that can be made to fit such metaphysics, but then what of the other religions which do not fit without imperialistic revisions? What prevents the pluralistic heroes of the Buddhist-Christian relationship from being Exclusivists with regard to all the other religions? Simply adding one to make two religions that get along is not Pluralism. So you can settle for a metaphysics that accommodates a Buddhist-Christian synthesis, but that is not Pluralism. You can settle for Hick's metaphysics that accommodates all religions, but that is still imposing metaphysics. The problem is not merely Exclusivism, which offers too particular a saviour, or Inclusivism, which offers too particular a salvation, but the problem remains even for the Pluralist who, like Hick, cannot help but subsume the religions under too particular a metaphysics. And, of course, the way out of that obstacle is to erase and redraw the boundaries once again, this time eschewing the search for any kind of transcendent Truth whatsoever. The solution to pursuing a particular (even if unknown) metaphysics is to see all metaphysics as created equal, with emphasis on the word created with the meaning of 'contrived'.

Yokota (2002:143) points out the problem with this Relativism - the idea that there is simply no metaphysical truth whatsoever, not accessible, not even existing - as it relates to the Buddhist-Christian relationship. First, he explains the position: 'One reality common to all beyond this multiplicity simply does not exist'. This kind of thinking 'is most thoroughly upheld by positivistic forms of the history of religions and has taken a radical turn in its most recent evolution through the influence of post-modern deconstructionism'. Have we finally stumbled upon that elusive view of complete objectivity? He goes on to point out:

Nevertheless, it too has an assumed perspective and is in no way totally free to be objective. The metaphysical assumptions that establish and have established religious faith are seen as untenable. The result of this radical religious empiricism is a thoroughgoing relativism. It gives sole credence to sociohistorical dynamics (which obviously must be recognised) with no acknowledgment of transcendent and universal claims of truth and the existence of ultimate reality which underlie these claims.... Each tradition is unto itself with no basis for mutuality and comparison among its many co-traditions. There is a chaotic multiplicity. This Babel-like condition may be the way things are, 
but that prospect spells doom for any one religious tradition to make any ultimate claims on it (sic) adherents. For the religiousminded, it would seem to be a fatal turn. (Yokota 2002:144)

Now, nothing has been said to necessarily disprove Relativism. As Yokota (2002:144) puts it, 'This Babel-like condition may be the way things are'. What is clear, however, is that Relativism imposes too exclusivistic a stance (a 'radical religious empiricism') for some people (indeed, for the many who believe their religion to be truly true). It is as if, for those interfaith scholars who have made it thus far through the cycle and still desire to say something not exclusivistic, the only thing they are able to say with confidence is, 'There are many religions, and they all teach what they teach'.

\section{A Buddhist answer}

So, to reference the above diagram again, consider the two vertical pairs: Relativism and Pluralism, Exclusivism and Inclusivism. As we have seen, the Buddhist-Christian interfaith scholar whose repudiation of exclusivity is consistent must avoid Exclusivism - because it is impolite to invite others into their circle, but must also avoid Inclusivism, because it is imperialistic to count them as already in. Likewise, she must avoid Relativism, lest there be no reality to experience, but must also avoid (Hick's) Pluralism - lest there be realities to exclude. What is left open to the consistent non-exclusivist is to define her own 'middle way' by way of eschewing all these extremes, and in some form emerging as a relativistic non-Relativist, pluralistic non-Pluralist, inclusivistic non-Inclusivist, unequivocally non-Exclusivist Buddhist-Christian. Again, the most straightforward statement that can be made about her is that she rejects anything exclusivistic. But that includes rejecting much more than just Exclusivism.

In fact, before Buddhism met interfaith scholarship, Buddhism would have been excluded as exclusivistic. Pristine Buddhism remains so. When Tanaka (2005:41-42) was caught off guard with his colleague's assertion that, according to her system, Tanaka was unsaved, Tanaka began reflecting on his own Shin Buddhist tradition. Tanaka began to realise that even the liberal-minded Shinran 'firmly believed that the Pure Land way was not only his choice but the only teaching appropriate for all people' (Tanaka 2005:42). Shinran taught that 'the Pure Land teaching was in a class by itself and superior to all other 84000 teachings, thus, exceptional'. Yokota (2002:146) too says of this most approachable of Buddhist sects, 'The classical material reflects a wholly negative attitude toward other religious traditions. Other Buddhist traditions are negated as well. Even strands of the Pure Land tradition are given a provisional status'.

Neither is Zen Buddhism, which joins Pure Land as a mainstay at the interfaith roundtable, as plastic as one might imagine. After years in gracious dialogue, Cobb (2008) conceded of a Zen Buddhist renowned for East-West harmonising:
Abe had been so original and helpful in his proposals for the development of Christian theology that he emboldened me to make suggestions about Buddhism. Abe had taught me so much. I hoped that I could teach him something about process that would enable him to accomplish his goal of making Buddhism more relevant to the concrete historical situation. But I could not. (pp. 120-121)

Another observer points out that while Abe asks westerners to repackage their ontology of 'God' and 'Being', yet, for him, the 'fundamental ontological category of Zen thought ("Nothingness") is never seriously challenged'. Perhaps 'Abe does indicate the need for Zen to learn from Western thought. Yet this need does not reach down to the essentials' (Dean 1989:58-59). As Abe (1994) himself put it:

The position of Buddhism towards other faiths is often characterised as one of tolerance by Western scholars. It may, however, be that the term 'tolerance' has been applied according to Western, especially Christian, standards, and is misleading in that it does not get to the heart of Buddhism. Grounded in nirvana, the Buddhist position is a 'positionless position' in the sense that, being itself entirely non-substantial, it lets every other position stand and work just as it is. Buddhism naturally does not exclude other faiths as false, but recognises the relative truths which they contain. (p. 6)

It is simply a misconception that Buddhists as a whole are as willing to budge on their beliefs as Christian interfaith scholars are eager to do with traditional Christianity. Cobb and Abe once summarised the Buddhist-Christian relationship, noting that, on the one hand, the 'dialogue has been more of a monologue, with Christians addressing the questions to Buddhists'. On the other hand, they comment, 'There is a pervasive Buddhist complacency toward, and disinterest in, Christianity, born out of the conviction of the superiority of "Emptiness" to "God," as a designation for Ultimate Reality' (McDaniel 1984:304). Interviews with senior Catholic and Buddhist nuns in the United States revealed similar lopsidedness: 'Several Buddhist nuns wondered why the Catholic nuns were looking to them for forms, and what this might mean about the state of the Catholic tradition. One Buddhist nun questioned whether the Catholic tradition lacked wholeness' (Bender \& Cadge 2006:237).

Well, what about the Buddha himself? Could it not be that he was more open to other paths, and his followers simply became more exclusivistic as the religion became more institutionalised? Makransky (2003:344) points out that although the Buddha spoke skillfully, reinterpreting Indic terms and speaking Buddhist truth in the language of other worldviews, the Buddha clearly critiqued opposing views. If there is an edge Buddhism has over Christianity in being less exclusivistic in its doctrines, it is that the Buddha recognised the ability of other paths to potentially help its adherents along in the virtues (e.g. nonattachment) conducive to the Buddhist path. Yet even where there are said to be alien elements conducive to the path, we must not rule out that such words of commendation could be merely upaya, meant to move as many as possible, by whatever means possible, onto the true path. And the Buddha's successors, the scholars 
and branch founders throughout the centuries, have carried themselves with the same conviction of correctness. Makransky (2003:358) concludes after a comparison with Catholic writings, 'most Buddhist thinkers, just as the authors of the Vatican documents, have not accepted a theological pluralism. They viewed the teaching of their tradition as uniquely efficacious in its salvific function'.

To dramatise this point, let us consider Chinese Shin patriarch Shandao's (613-681) Parable of the White Path (Shandao 2014:84-86). Attacked by thugs and beasts, a traveller flees west until he stops short at what he sees just below him. If he keeps going, he will surely fall into one of two rivers, separated by an incredibly narrow $4-5$-inch path. One river swells with violent waters; the other leaps up and down with flames. Both are immeasurably deep and long. If he goes back or stays, there is certain death. His only option is to continue west along this narrow path, with flames licking at his feet and waves sloshing over the path. As he takes his first steps, a voice from the East says, 'O traveller, just resolve to follow the path forward! You will certainly not encounter the grief of death. But if you stay where you are, you will surely die'. Just then, a voice from the West echoes, ' $O$ traveller, with mind that is single, with right-mindedness, come at once! I will protect you. Have no fear of plunging to grief in the water or fire'. With new resolve, the traveller 'advances directly forward with mind that is single, forthwith reaches the western side, and is free forever of all afflictions'. Now, the attackers are one's own treacherous attachments to ego. The fire and water are the poisons of greed and anger. The encourager from the East is none other than Sakyamuni, the historic Buddha, and the speaker from the West is Amida Buddha from his western paradise. The narrow path going west is the pure mind set on rebirth in the Amida's Pure Land.

\section{An interfaith problem}

The point, of course, is that, if both Christianity and Buddhism claim in various ways to be the 'narrow path' (e.g. Mt. 7:13), it seems difficult if not impossible to please both religious founder and interfaith scholar. Indeed, even cycling through the progressively more open views provided by interfaith dialogue - Exclusivism, Inclusivism, Pluralism, Relativism it is next to impossible to land anywhere that is not labelled too exclusivistic in some sense. Even if you somehow disavow all connections to particular saviours, salvations, and metaphysics, you find yourself in a secularistic wasteland, according to which every religious adherent is patronised as an 'anonymous simpleton'. The question becomes not, 'What is exclusivistic so that we might banish its last traces from our midst', but rather, 'What is not exclusivistic so that we might actually have something to build upon?'

\section{A Christian reality}

The Christian cannot resist asking the question, what if Christianity was, in fact, revealed? The fact is that, even if it were true that God did exist and revealed himself once-andfor-all in Jesus and then told people to tell everybody the news, we could not, according to these interfaith scholars, believe it. The logic seems to be that, even if God revealed something, humans could never comprehend it. Should God create humans in his image so that humans could, in fact, understand, and even if He communicated the message, confirming it through miracles, still the message should not be held with conviction because it would be setting itself up against the experiences of others with their versions of the Ultimate. In the end, these interfaith scholars are not so much attacking exclusivity (because they themselves are not above excluding certain religious beliefs) as they are averse to the possibility of certain types of reality.

\section{Acknowledgements Competing interests}

The authors declare that they have no financial or personal relationships which may have inappropriately influenced them in writing this article.

\section{Authors' contributions}

D.M. is the author of the doctoral thesis A comparison of Buddhist compassion to Christian love, the thesis of which an excerpt was reworked into this article. H.S. was promoter for the thesis, and W.C. was assistant promoter.

\section{References}

Abe, M., 1994, 'Suffering in the light of our time, our time in the light of suffering', The Eastern Buddhist 27(2), 1-13.

Bender, C. \& Cadge, W., 2006, 'Constructing Buddhism(s): Interreligious dialogue and religious hybridity', Sociology of Religion 67(3), 229-247.

Beverley, J.A., 2001, 'Buddhism's guru', Christianity Today 45(8), 64-72.

Brown, C.A., 1999, 'Can Buddhism save? Finishing resonance in incommensurability', Cross Currents 49(2), 164-196.

Carlson, J., 2003, 'Responses', Buddhist - Christian Studies 23, 77-83.

Cobb, J.B., 2008, 'Masao Abe', Buddhist - Christian Studies 28, 119-121.

Corless, R., 2007, 'The Christian exploration of non-Christian religions: Merton's example and where it might lead us', Merton Annual 20, 206-224.

Cowan, D.E., 2000, 'No harmony: Some notes on Evangelical Christian response to Buddhism', Religious Studies and Theology 19(2), 17.

Dean, T., 1989, 'Masao Abe on Zen and Western thought', The Eastern Buddhist 23(2), $48-77$.

Fors, J.O., 2006, 'Mutual transformation: John Cobb's theology of religions and his dialogue with Buddhism', Swedish Missiological Themes 94(1), 81-96.

Fredericks, J., 2003, 'The Catholic church and the other religous paths: Rejecting nothing that is true and holy', Theological Studies 64(2), 225-254.

Gross, R.M., 2005, 'Religious identity and openness in a pluralistic world', Buddhist Christian Studies 25, 15-20.

Haug, K.S., 2006, 'Did Jesus teach about wisdom and kamma? A critical analysis of a Buddhist Bible interpretation', Swedish Missiological Themes 94(1), 55-79.

Hick, J., 2006, 'Is Christianity the only true religion, or one among others?', viewed 6 August 2011, from http://www.johnhick.org.uk/jsite/index.php?option=com content\&view=article\&id=49:isonly\&catid=37:articles\&ltemid=58

Knitter, P.F., 2012, 'A “hypostatic union" of two practices but one person?', BuddhistChristian Studies 32, 19-26.

Knitter, P.F. \& Abe, M., 1988, 'Spirituality and liberation: A Buddhist-Christian conversation', Horizons 15(2), 347-364.

Knitter, P.F. \& Netland, H.A., 2013, 'Can only one religion be true?: A dialogue', in R.B. Stewart (ed.), Can only one religion be true?: Paul Knitter and Harold Netland in dialogue, Fortress Press, Minneapolis, MN.

Koyama, K., 2002, 'What can Christians contribute to the understanding of Buddhism in Thailand, Part I', Swedish Missiological Themes 90(1), 77-83. 
Makransky, J., 2003, 'Buddhist perspectives on truth in other religions: Past and present', Theological Studies 64(2), 334-361.

McCoy, D., 2015, 'A comparison of Buddhist compassion to Christian love', PhD dissertation, North-West University, Potchefstroom.

McDaniel, J., 1984, 'Zen Buddhism and prophetic Christianity', Encounter 45(4), 303-323.

Phan, P.C., 2006, 'Global healing and reconciliation: The gift and task of religion, a Buddhist-Christian perspective', Buddhist - Christian Studies 26, 89-108.

Schmidt-Leukel, P., 2003, 'Buddhism and Christianity: Antagonistic or complementary?', Studies in World Christianity 9(2), 265-279.

Scott, D., 1985, 'Christian responses to Buddhism in premedieval times', Numen 32(1) 88-100.
Shandao, 2014, 'Parable of the white path', in E. Andreasen (ed.), Popular Buddhism in Japan: Shin Buddhist religion and culture, Routledge, Abingdon.

Tanaka, K.K., 2005, 'Acceptance of the other as a similarly valid path and awareness of one's self-culpability: A deepening realisation of my religious identity through dialogue', Buddhist - Christian Studies 25, 41-46.

Weakland, R.G., 2008, 'Thomas Merton's Bangkok lecture of December 1968', Buddhist-Christian Studies 28, 91-99.

Yokota, J.S., 2002, 'Shin Buddhism and the Christian-Buddhist dialog: What is to be gained?', Pure Land 18-19, 138-158.

Yong, A., 2011, 'On doing theology and Buddhology: A spectrum of Christian proposals', Buddhist - Christian Studies 31, 103-118. 